\title{
EVIDENCE FOR PHOTOPERIODIC CONTROL OF PROLACTIN RELEASE IN RAMS
}

\author{
J. PELLETIER \\ I.N.R.A.-Station de Physiologie de la Reproduction, \\ 37380-Nouzilly, France
}

(Received 16th April 1973)

Prolactin is known to increase the effect of testosterone on male accessory sex glands (Segaloff, Steelman \& Flores, 1956), and to have a synergistic action with LH on spermatogenesis (Bartke, 1971) and on testicular androgen secretion (Hafiez, Bartke \& Lloyd, 1972). It has been shown also that the male pituitary releases prolactin into the blood in the rat (Amenomori, Chen \& Meites, 1970) and the human (Jacobs, Mariz \& Daughaday, 1972). Little is known, however, about factors which regulate prolactin secretion in this sex.

In the female rat, antagonism between prolactin and gonadotrophin secretion has been shown following drug treatment (Ben-David, Danon \& Sulman, 1971). It is also suggested by the fact that ovariectomy produces a decrease in serum prolactin (Amenomori et al., 1970), an effect which is the reverse of the classical increase of FSH and LH in the blood observed in this condition. It seemed of interest, therefore, to study the influences on prolactin release of factors known to regulate the gonadotrophic function in the male. It has been demonstrated previously (Pelletier, 1971) that two factors are mainly involved in LH synthesis and release in the ram: (a) testicular androgens and (b) photoperiodic variations. The plasma $\mathrm{LH}$ level is low when the days are long (16 hr light) but increases dramatically as soon as the light photoperiod decreases from $16 \mathrm{hr}$ to $13 \mathrm{hr} 20 \mathrm{~min}$. With further decreasing light photoperiod to $8 \mathrm{hr}$, the LH level only declines slowly, so it is still high during the shortest days.

The influence of androgens and light on prolactin secretion have been examined by determining plasma levels of prolactin in normal and castrated rams under various photoperiod lengths.

In Exp. 1, thirty 2-year-old Ile-de-France rams were submitted to an experimentally 'shortened' annual photoperiodic cycle (Text-fig. lb), a procedure which amplifies the influence of light rhythms. The maximum and the minimum periods of daily illumination were $16 \mathrm{hr}$ and $8 \mathrm{hr}$, respectively, which are the natural extremes of photoperiod at the latitude of Tours $\left(47^{\circ} \mathrm{N}\right)$. The animals were allotted to two equal groups and submitted to two opposite patterns of gradually changing daylight hours between these extremes. A complete cycle took 6 months. Eight rams of each group were entire and the other seven were castrated. Blood was collected from the jugular vein once a month from all animals, beginning after completion of one entire 6 -month cycle and 6 weeks after the surgical operation in the case of the castrated rams. All plasmas were kept frozen until they were analysed simultaneously for their prolactin con- 

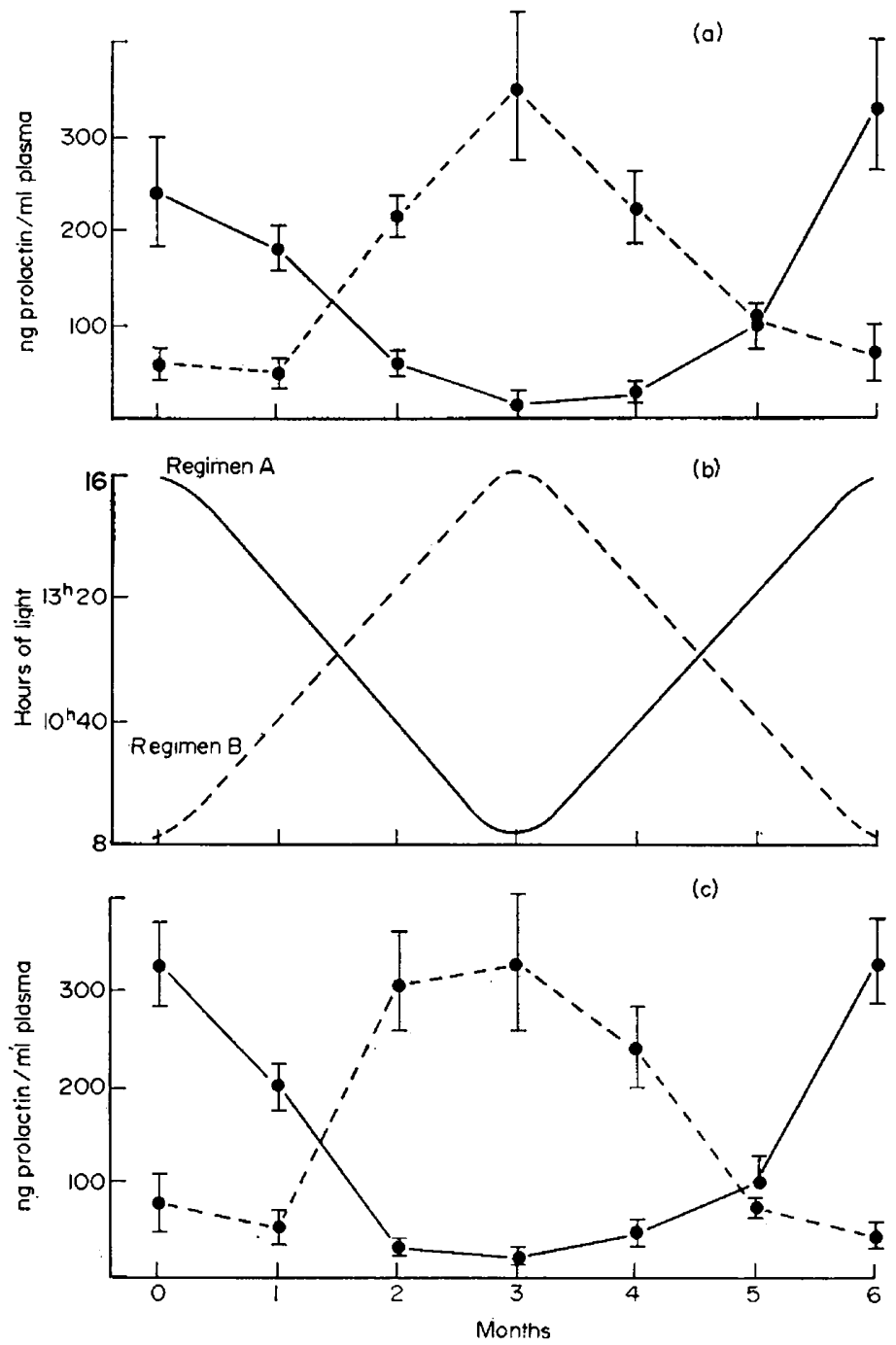

Text-Fig. 1. Experimental regimens (A and B) of 'shortened' annual photoperiodic rhythm (b) and the mean plasma prolactin levels (vertical bars represent \pm S.E.M.) of two groups of eight entire (a) and seven castrated (c) rams submitted to two opposite light regimens. Continuous line: animals under light regimen A; broken line: animals under light regimen $\mathbf{B}$.

centration by specific radioimmunoassay according to the method described by Kann (1971).

In Exp. 2, thirty-two other Ile-de-France rams were allotted to two equal groups and submitted to opposite photoperiodic rhythms for two successive cycles similar to the preceding ones. Each group contained two sub-groups of eight entire males and eight males castrated 70 days before the end of the second light cycle. At the same time as castration, half the animals of each of the four sub-groups were injected intramuscularly with $100 \mathrm{mg}$ testosterone propionate in $2 \mathrm{ml}$ oil every $2 \mathrm{nd}$ day, the other (control) animals received only the 
vehicle. After the 35th injection, the light duration being then $16 \mathrm{hr}$ or $8 \mathrm{hr}$ blood samples were collected for prolactin assay.

The variations in plasma prolactin levels in Exp. 1 in intact and castrated animals are summarized in Text-figs 1 (a) and 1 (c) respectively. Text-figure 1 (b) shows the concurrent pattern of changing photoperiod.

The main feature is the parallelism between variations of light photoperiod and the plasma prolactin levels, both in intact rams (correlation coefficient, $r=+0.888, P<0.001)$ and castrated animals $(r=+0.887, P<0.001)$. In both groups, maximal prolactin values were found when animals were exposed to light for $16 \mathrm{hr}$; conversely, the lowest values corresponded to the shortest light photoperiod. The rise in prolactin level began after the commencement of the increased light photoperiod, between $10 \mathrm{hr} 40 \mathrm{~min}$ and $13 \mathrm{hr} 20 \mathrm{~min}$ of light. The reduction of prolactin levels began immediately the light photoperiod decreased.

In the 3rd month, the plasma prolactin concentration in 'long day' rams was approximately sixteen times higher than that of 'short day' rams, both in entire and castrated animals. Prolactin levels in normal rams and castrated ones were very similar when they were exposed to the same light regimen (correlation coefficient, $r=+0.95 ; P<0.001)$.

Table 1. Influence of testosterone propionate treatment on prolactin levels in entire and castrated rams exposed to $8 \mathrm{-hr}$ and 16-hr light photoperiods

\begin{tabular}{l|c|c|c|c}
\hline \multirow{2}{*}{ Treatment } & \multicolumn{4}{|c}{ Prolactin concentration $(\mathrm{ng} / \mathrm{ml}$ plasma $)$} \\
\cline { 2 - 5 } & $\begin{array}{c}\text { Entire } \\
(8 \mathrm{hr})^{*}\end{array}$ & $\begin{array}{c}\text { Castrated } \\
(8 \mathrm{hr})^{*}\end{array}$ & $\begin{array}{c}\text { Entire } \\
(16 \mathrm{hr})^{*}\end{array}$ & $\begin{array}{c}\text { Castrated } \\
(16 \mathrm{hr})^{*}\end{array}$ \\
\hline $\begin{array}{c}\text { Vehicle-treated }(n=4) \\
\begin{array}{c}\text { Testosterone propionate- } \\
\text { treated } \dagger(n=4)\end{array}\end{array}$ & $31 \cdot 0 \pm 10 \cdot 3$ & $61 \cdot 9 \pm 21 \cdot 0$ & $248 \cdot 2 \pm 44 \cdot 1$ & $304 \cdot 3 \pm 56 \cdot 5$ \\
\hline
\end{tabular}

Results are expressed as means \pm S.E.M.

* Daily photoperiod length at the time of blood collection.

$\uparrow 100 \mathrm{mg}$ every second day for 70 days.

The results of Exp. 2 are shown in Table 1. The plasma prolactin levels were higher in rams exposed to $16 \mathrm{hr}$ of light than in those exposed to $8 \mathrm{hr}$. The levels were similar for entire and castrated animals under the same light regimen. The values for castrated rams were sometimes higher, but not significantly. The table also shows that in neither case did plasma prolactin levels differ in androgen-treated and control animals.

The absence of variations in prolactin concentration following either castration or testosterone propionate injections suggests that there is no antagonism between the release of prolactin and of gonadotrophins. In particular, androgenic treatment does not influence prolactin secretion in a range where it markedly decreases LH release (Pelletier, 1971). Consequently, it appears from this study that there is little interference by testicular androgens on prolactin release.

There is, however, a clear relationship between the light photoperiod duration and the plasma prolactin level. Such a relationship was suggested by 
Saji (1966) who used a haemagglutination-inhibition test to study the plasma prolactin concentration in the ewe under natural light conditions from May to September. In contrast to the present results, minimal values were found in July, i.e. during long daily photoperiods. The difference may arise from the different sexes studied, but also from the two light regimens used. The high correlation coefficient between the hormonal level and the length of daily illumination made negligible here the possible occurrence of other sources of variation such as stress (Neill, 1970) or circadian rhythms which have been demonstrated in the rat (Dunn, Arimura \& Scheving, 1972) and in cattle (Swanson \& Hafs, 1971).

The results agree with findings obtained in duck and quail where the increase of daily photoperiod produced an increase of the pituitary prolactin content (Gourdji \& Tixier-Vidal, 1966; Gourdji, 1970). This effect was thought to be due to an improvement in both the synthesis and the release of prolactin. In this case, however, prolactin release would parallel gonadotrophin secretion since the increasing photoperiod stimulates testicular growth. Conversely, in the ram exposed to a 6-month light rhythm, the long light photoperiod results in low LH levels (Pelletier, 1971) and a low gonad weight (Ortavant, 1961).

Whatever the level at which light influences hypothalamic activity, one can conclude that, in the ram, photoperiodism acts as a synchronizer of prolactin release.

Thanks are due to Dr G. Kann for making available the materials for the radioimmunoassay of plasma prolactin.

\section{REFERENCES}

Amenomori, Y., Ghen, C. L. \& Meires, J. (1970) Serum prolactin levels in rats during different reproductive states. Endocrinology, $\mathbf{8 6}, 506$.

BARTKE, A. (1971) Effects of prolactin on spermatogenesis in hypophysectomized mice. F. Endocr. 49, 311.

Ben-David, M., Danon, A. \& Sulman, F. G. (1971) Evidence of antagonism between prolactin and gonadotrophin secretion: effect of methallibure on perphenazine-induced prolactin secretion in ovariectomized rats. F. Endocr. 51, 719.

Dunn, J. D., Arimura, A. \& Scheving, L. E. (1972) Effect of stress on circadian periodicity in serum $\mathrm{LH}$ and prolactin concentration. Endocrinology, 90, 29.

Gourdjr, D. (1970) Prolactine et relations photosexuelles chez les oiseaux. Colloques int. Cent. natn. Rech. scient. 172, 233.

Gourdji, D. \& Tixier-Vidal, A. (1966) Variations du contenu hypophysaire en prolactine chez le canard Pékin mâle au cours du cycle sexuel et de la photostimulation expérimentale du testicule. C. r. hebd. Séanc. Acad. Sci., Paris, D, 262, 1746.

Hafiez, A. A., Bartke, A. \& Lloyd, C. W. (1972) The role of prolactin in the regulation of testis function: the synergistic effects of prolactin and luteinizing hormone on the incorporation of $\left[1-{ }^{14} \mathrm{C}\right]$ acetate into testosterone and cholesterol by testes from hypophysectomized rats in vitro. F. Endocr. 53, 223.

Jacobs, L. S., Mariz, I. K. \& Daughaday, W. H. (1972) A mixed heterologous radioimmunoassay for human prolactin. 7. clin. Endocr. Metab. 34, 484.

KanN, G. (1971) Dosage radioimmunologique de la prolactine plasmatique chez les ovins. C. r. hebd. Séanc. Acad. Sci., Paris, D, 272, 2934.

NeILl, J. D. (1970) Effect of "stress' on serum prolactin and luteinizing hormone levels during the estrous cycle of the rat. Endocrinology, 87, 1192.

Ortavant, R. (1961) Réponses spermatogénétiques du bélier à différentes durées d'éclairement. 4th Int. Congr. anim. Reprod., The Hague, 21, 236. 
Pelletier, J. (1971) Infuence du photopériodisme et des androgènes sur la synthèse et la libération de LH chez le belier. Thèse Doc. Sci., University of Paris.

SAJI, M. A. (1966) An immunological estimation for prolactin in sheep blood. In: Reproduction in the Female Mammal. Eds. C. E. Lamming and E. G. Amoroso. Butterworths, London.

Segaloff, A., Steelman, S. L. \& Flores, A. (1956) Prolactin as a factor in the ventral prostate assay for luteinizing hormone. Endocrinology, 59, 233.

Swanson, L. V. \& Hafs, H. D. (1971) LH and prolactin in blood serum from estrus to ovulation in Holstein heifers. F. Anim. Sci. 33, 1038. 